Volume 13

Issue 2 Rethinking Genocide, Mass Atrocities,

and Political Violence in Africa: New Directions,

Article 18

New Inquiries, and Global Perspectives

6-2019

\title{
Book Review: Death, Image, Memory: The Genocide in Rwanda and its Aftermath in Photography and Documentary Film
}

Scott Ahearn

Harvard Extension School, Harvard University

Follow this and additional works at: https://digitalcommons.usf.edu/gsp

\section{Recommended Citation}

Ahearn, Scott (2019) "Book Review: Death, Image, Memory: The Genocide in Rwanda and its Aftermath in Photography and Documentary Film," Genocide Studies and Prevention: An International Journal: Vol. 13: Iss. 2: 162-164.

DOI:

https://doi.org/10.5038/1911-9933.13.2.1688

Available at: https://digitalcommons.usf.edu/gsp/vol13/iss2/18

This Book Review is brought to you for free and open access by the Open Access Journals at Digital Commons @ University of South Florida. It has been accepted for inclusion in Genocide Studies and Prevention: An International Journal by an authorized editor of Digital Commons @ University of South Florida. For more information, please contact digitalcommons@usf.edu. 
Book Review: Death, Image, Memory: The Genocide in Rwanda and its Aftermath in Photography and Documentary Film

\section{Acknowledgements}

(1) Piotr Cieplak, Death, Image, Memory: The Genocide in Rwanda and its Aftermath in Photography and Documentation (London: Palgrave Macmillan, 2017), 4. (2) Piotr Cieplak, Death, Image, Memory: The Genocide in Rwanda and its Aftermath in Photography and Documentation (London: Palgrave Macmillan, 2017), 27. (3) Piotr Cieplak, Death, Image, Memory: The Genocide in Rwanda and its Aftermath in Photography and Documentation (London: Palgrave Macmillan, 2017), 194. 


\title{
Book Review: Death, Image, Memory: The Genocide in Rwanda and its Aftermath in Photography and Documentary Film
}

\author{
Scott Ahearn \\ Harvard Extension School, Harvard University \\ Cambridge, Massachusetts, USA
}

Death, Image, Memory: The Genocide in Rwanda and its Aftermath in Photography and Documentation Piotr Cieplak

London, Palgrave Macmillan, 2017

230 Pages; Price: \$79.99 Paperback

Reviewed by Scott Ahearn

Harvard Extension School, Harvard University

With 2019 marking the twenty-fifth anniversary of the genocide in Rwanda, a country haunted by unthinkable loss faces another chapter: contending with the loss of its survivors. This poses a challenge to Rwandans' remembrance, bringing urgency to attributing identity and stories to victims. Piotr Cieplak's book, Death, Image, Memory: The Genocide in Rwanda and its Aftermath in Photography and Documentation, is timely as an exploration of the body of documentary imagery developed since 1994 and its "uncomfortable coexistence with the genocide and its aftermath." ${ }^{1}$ Cieplak examines what purposes are being asked of this imagery - as remembrance, as documentation, as forensic evidence-and in what contexts it has succeeded. He argues that the ability of these images to capture the genocide-already an insurmountable task - is further complicated by the mutability of their meaning depending on their context and on the individual receiving them.

The works chosen are, by his own admission, a cross section that cannot hope to be comprehensive, yet Cieplak's book benefits from offering in-depth analysis of specific collections rather than casting too wide a net. Each of his chapters is a self-contained exploration of the power of a type of imagery, and of the complexities each medium finds in attempting to contribute to remembrance. Before looking at the collections, his first chapter delves into a theoretical analysis of imagery depicting atrocity, drawing on the ideas of Susan Sontag and Roland Barthes, among others; this chapter, the most esoteric in scope and the least specific to Rwanda, will perhaps be of interest more to semioticians and filmmakers than to historians or students of global politics. With the succeeding chapters, however, Cieplak will powerfully immerse any reader into the raw horror that brought about such images.

Chapter 2 focuses on still photography, looking at Gilles Peress' photographic book The Silence and Sebastião Salgado's Migrations: Humanity in Transition. He weighs Salgado's more aesthetic compositions against Peress' more neutral, forensic style, and examines the risks of bringing an aesthetic eye into subject matter where any concept of beauty or artistry finds no place. His third chapter is devoted to pre-genocide imagery that has been collected at the Kigali Genocide Museum, departing from the work of professional photographers to examine the role of everyday snapshots in the task of documentation and remembrance. Chapter 4 segues into moving images, with a breakdown of the only widely recognized footage of actual killing in the Rwandan genocide, as well as of the 2008 documentary Iseta in which the cameraman who captured that footage, Nick Hughes, returns to Rwanda in an attempt to restore identity to the victims and perpetrators that he filmed. Finally, Chapter 5 looks at the growing community of Rwandan filmmakers and the issues they face in both capturing remembrance and moving into a Rwandan identity beyond that of genocide survivors.

Cieplak's examination of aesthetics in still imagery is interesting, and is perhaps the theme most evenly relevant to filmographers, ethicists, and historians, all of whom would find interest in this book. In comparing the more objective work of Peress with the more artistic composition

${ }^{1}$ Piotr Cieplak, Death, Image, Memory: The Genocide in Rwanda and its Aftermath in Photography and Documentation (London, Palgrave Macmillan, 2017), 4. 
of Salgado, he introduces a very worthwhile debate on the merits and dangers of aesthetic values when capturing atrocities. The discussion would benefit from an alignment of what is meant by "aesthetic" when addressing such images. If we think of aesthetics as a principle of satisfaction, then it is of course absurd to give it a place in this discussion. Yet the term "aesthetic" may inhabit a totally different realm here. Are aesthetics achieved when the full potential impact of an image is expressed? As the author discusses the stark horror of a body lying at the base of a church, one must wonder: Is the photographer inappropriately giving himself over to aesthetics in composing an image such that this juxtaposition is clearly seen? The discussion is complex; foreign documenters of the aftermath must check themselves against artistic opportunism. Yet a dry, forensic approach, executed in the hope of avoiding such opportunism, might not only miss impactful images but also read as a cold, perfunctory job that only exacerbates insult. Therefore judging aesthetics as a trap without adjusting for this context can lead the photojournalist down the opposite path of what would have been respectful.

Cieplak's theme of the importance of contextualization in best illustrated in his chapter on pre-genocide imagery. These images, always focused on eventual victims of the killings, have their origins in a context of either everyday life or a joyous occasion. Their present context as memorials of course delivers a cutting aspect to the innocence of their original purpose. It is in our reading of them in their newfound context that they assume a mantle of testimony and remembrance. It is significant to Rwandans' story that as they continue to contribute images even now to the KGM, many choose to preserve their originals in the security of the museum and retain only copies - an acknowledgement of their fragility as physical memories.

The author's discussion of Iseta reveals the complexity of readdressing a stunning cruelty, as two victims whose death became famous through filmographer Nick Hughes's lens remained powerless in life and anonymous in death. Hughes's return trip to Rwanda is an attempt to restore identity to the victims, yet finding their story risks opening tremendous wounds for the victims' family. Here Cieplak's argument is plain to see; remembrance for one person is an uninvited tug through misery for another. For the victims' family, such memorialization may have been welcome at some point in their years of coping, yet they had no say in the terms of when that memorialization would come.

Cieplak masters the material and directs the reader to a fascinating array of work. I find two issues he has downplayed in his examination of Western neglect of the genocide; the first is his contention that "the absence of the actual acts of killings from the visual representations... adds to the narrative of the genocide having been missed." ${ }^{2}$ While the West remained shamefully absent despite ample warnings about the dire situation leading up to the genocide, his accounting for the lack of genocidal imagery seems to disregard the inherent taboo against documenting moments of death-an ethic worth considering even if to argue it was worth overcoming. This taboo, guarding against infringements on the dignity of the victim (and also on the receptivity of the viewer), severely challenges the ethics of not only saving and disseminating such an image but also capturing it in the first place, and playing the role of gawking bystander when killing is occurring. Nick Hughes's unique footage of two murders during the genocide was taken from a rooftop, affording it a sufficient distance to both render the victims anonymous and avoid (one hopes) the insult of recording within view of the dying. There is no question that the West failed Rwanda. Yet a separate failing the Western media must face in light of such horrors is the lack of resolve on how to expose tragedy without adding the element of exploitation at precisely the moment when victims are most dehumanized.

Secondly, Cieplak has chosen to downplay a key potential purpose of documenting atrocity: exposing the international community's failure in its post-Holocaust commitment: Never Again. His dismissal of this purpose is no accident, as he mentions the commitment in both his introduction and his conclusion, and his final tone concerning such a purpose is downright pessimistic, stating "how inconsequential and short-lived this outrage is." ${ }^{3}$ With that said, the body of his book all but

\footnotetext{
${ }^{2}$ Ibid., 27.

${ }^{3}$ Ibid., 194.
} 
refuses to engage with the idea. Though his skepticism is well-informed, the idea, given his topic, is above being ignored; as smartphones and social media make documenters of us all, these images lay bare how brittle our Nie wieder promise has been, and how we will continue to fail that promise unless we direct the purpose of genocide imagery toward the future as well as the past.

Death, Image, Memory is highly thoughtful and deeply researched, and has much to offer any student of history and human rights, especially as Rwanda's survivors face an era of divergent needs to memorialize and heal. Readers who are not focused on filmography and the theory of imagery may, in the first chapter, crave more tangible connection to the powerful story of Rwanda, but that discussion will come in all subsequent sections, with a rich and respectful treatment of a moving collection of imagery. 